\title{
CHARGE-NUMBER OF PULSES-CONVERTER
}

\author{
V. L. Morokhovskii, V. V. Morokhovskyi, V. N. Pirogov \\ National Science Center "Kharkiv Institute of Physics and Technology", 61108 Kharkiv, Ukraine
}

(Received June 20, 2020)

It is described the charge-number of pulses-converter, which was successfully applied in the "Program-apparatus complex for investigation of gamma- and X-rays radiations, generated by relativistic electrons in crystals" [1] at Kharkiv linear electron accelerators. This device is in the condition for high energy electron (positron) beam charge measurements with accuracy $2 \cdot 10^{-10} \mathrm{C}$ and current measurements in the range of $10^{-10} \ldots 10^{-8} \mathrm{~A}$.

PACS: 03.65.Pm, 03.65.Ge, 61.80.Mk

\section{INTRODUCTION}

Measurements of the coherent radiations spectra of relativistic electrons interacting with crystals, such as Coherent Polarization Radiation [2], Coherent Bremsstrahlung [3] or Channeling Radiation [4], usually are done with the electron beam current of order of $10^{-8} \ldots 10^{-9} A$. For measurements of cross sections of mentioned processes in absolute units it's necessary to measure the charge and the current of beam of accelerated electrons with high accuracy. For carrying out our experiments $[5,6]$ we designed and made the charge-number of pulses-converter, analogous with semi-conductive integral scheme of potentialfrequency converter, like Russian K

\section{HOW DOES THIS DEVICE WORK ?}

Block-scheme of the charge-number of pulsesconverter, that is the prototype of our scheme is displayed in the Fig.1. Using this scheme we can analyze the principle of work of this device.

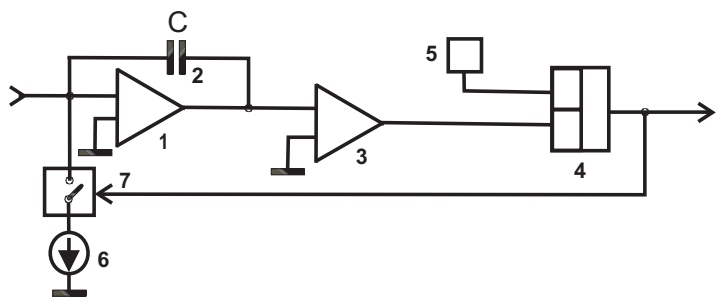

Fig.1. The structure of charge-number of pulses convertor: 1-operational amplifier; 2-capacity; 3-comparator; 4-scheme of coincidence; 5-pulse generator; 6-stable current source; 7-operational switch

Charge integrator is compounded from operational amplifier (1) and capacity C (2). Entered current $I(t)$ is integrated in capacity $C$. Charge $Q(t)=\int_{0}^{T} I(t) d t$ increases the potential in the exit of the operational amplifier $U(t)=C^{-1} \cdot Q(t)$. When this potential becomes higher than upper threshold of comparator $U(T)>u_{c 2}$, the comparator (3) changes its state. The step of potential is generated at the comparator exit. Then the scheme of coincidence (4) allows to pass the pulses from pulse generator (5) to the operated switch (7). By this way the source of the stable current $I$ (6) switches on the time of pulse duration $\tau$ and generates the standard portion of charge in the entrance of integrator: $q=i \cdot \tau$. This portion of charge has the opposite sign respectively the charge measured. So it makes the potential at the exit of operational amplifier (1) lower. The scheme of coincidence (4) allows to pass the pulses from pulse generator (5) to the operational switch (7) till the potential at the exit of operational amplifier becomes lower than comparator threshold $U(T+2 \tau N)<u_{c 1}$, where $Q(T+2 \tau N)=\int_{0}^{T+2 \tau N} I(t) d t-q N$. And we have $\mathrm{N}$ standard pulses at the exit of the scheme of coincidence.

\section{THE PRINCIPLE SCHEME OF CHARGE-NUMBER OF PULSES-CONVERTER}

The range of the current measurement is limited by the current leakage through the operated switch and entrance of operational amplifier. Exactness of the charge-number of pulses transformation is limited by stability of pulse generator and stable current source. High stability of pulse generator can be provided with using quartz (let's use quartz with frequency $\left.8 \cdot 10^{6} s^{-1}\right)$. Stable current source can be assembled using transistors with low inverse current. Source stability can be increased by using high stable stabilitron. So the stabile current $I$ can be about $0.2 \mathrm{~mA}$ with stability about $0.1 \%$. In this case the value of the portion of charge is $q=1.25 \cdot 10^{-10} \mathrm{C}$.

To lowest leakage due to the transistors inverse current can be the order of $10^{-11} A$. In our scheme this is the main source of error.

\footnotetext{
*Corresponding author E-mail address: victor@kipt.kharkov.ua
} 


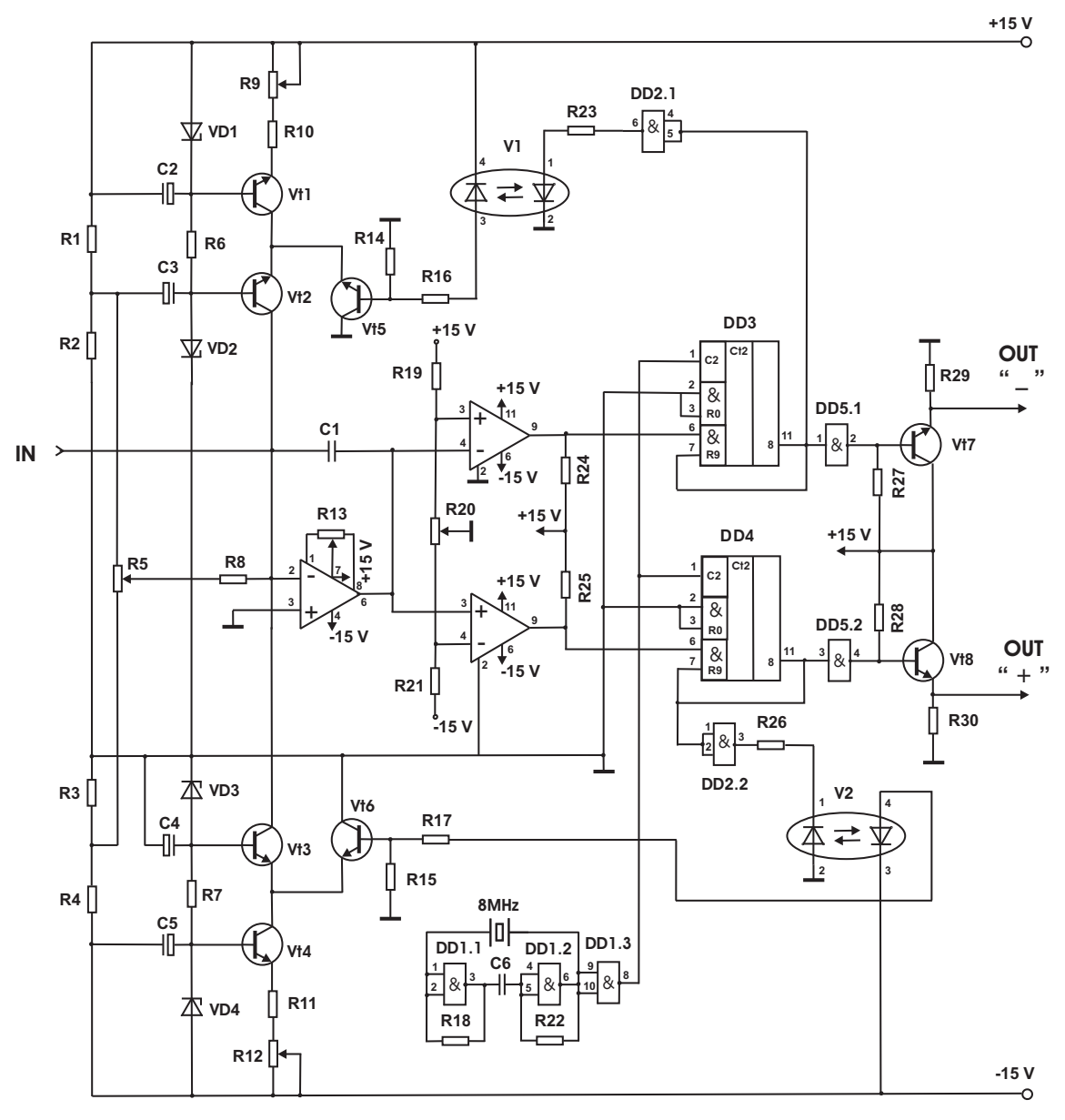

Fig.2. Principle scheme of charge-number of pulses-convertor

Taking into account that efficiency of the secondary emission monitor is order of 0.1 , we can measure the charge with error about $1 \%$ with confidence, when the beam current is order of $10^{-8} \mathrm{~A}$ or higher. It is possible to improve the result by selecting of transistors with the best parameters. However the idea of the leakage compensation is more productive. For this purpose we need to design two symmetrical current sources with the same value of current, but opposite directions of currents, and switch them to the entrance of integrator. On this way we can make the lowest limit of measured current (and charge) 10 times lower. Besides we get additional possibility to measure the charges with different signs.

The principle scheme of our device is shown in Fig.2.

The pulses appear in the one of the two exits, depending on the charge sign. Such scheme can be applied for relativistic electron beam charge measurements both with secondary emission monitor and Faraday Cup. To realize this idea we use two comparators and two schemes of coincidence.

Our scheme is symmetrical and has one important peculiarity. In order to avoid the instability (self generation), it is necessary to select the integrating capacity $C 1>i \cdot \tau /\left(u_{c 2}-u_{c 1}\right)$. For precessional compensation of the remain current leakage we use the potential divider, which is assembled from thermicstable resistors $R_{1}-R_{5}, R_{8}$ and is connected with entrance of the operational amplifier.

Our device can be tuned by three steps:

1. It is necessary to make equal the current of two symmetrical current stabilizers $\left(i^{+}\right)=\left(i^{-}\right)$by tuning resistors $R_{9}, R_{11}$

2. Having circuit integrator entrance, the thresholds of symmetrical comparators are made equal $\left(u_{c 2}^{+}\right)=\left(u_{c 2}^{-}\right)$by tuning resistor $R_{20}$;

3. Having uncircuit integrator entrance, the precision compensation of difference between remain leakages must be made by tuning resistor $R_{5}$.

Our device (see Fig.2) was built of Russian components. The microchips are: $D A 1$ (К544УД1A); DA2, DA3-(K554CA3); DD1, DD2-(K155ЛA3); DD3， DD4-(K155ИE2); DD5(К155ЛН3). The transistors are: VT1, VT2, VT5-(KT3107); VT3, VT4, VT6-(KT3102); VT7, $V T 8-(K T 6305)$. The stabilizer diodes are: VD1,

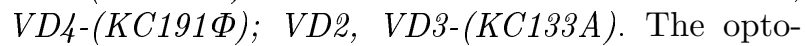
electronics are: V1-(АОД101A); V2-(АОД101Б). The following capacities were got out: C2, C3, $C 4, C 5=330 \mu \mathrm{F} \cdot 15 \mathrm{~V}$. And the following resistors were got out: $R 1, R 4, R 5, R 19, R 21=10 \mathrm{k} \Omega ; R 2$, $R 3, R 24, R 25, R 27, R 28=1 k \Omega ; R 6, R 7=300 \Omega$; $R 8=47 G \Omega ; \quad R 9, \quad R 12=4.7 \mathrm{k} \Omega ; \quad R 10, \quad R 11=39 k \Omega ;$ 
$R 14, R 15=24 k \Omega ; \quad R 16, R 17=1.8 k \Omega ; \quad R 18, R 22=390 ;$ R20,R23, R26=330; R29, R30=1.3k .

The possibility of current measurement in the range $10^{-10} \ldots 10^{-8} A$ was shown in $[5,6]$, where our device was used. The accuracy of charge measurement was $2 \cdot 10^{-10} C$.

The research described in this publication was supported by Grant No UA3000 from the International Science Foundation.

\section{References}

1. D. I. Adeishvily, I. F. Emel'yanchik,

V. B. Gavrikov, V. L. Morokhovskii, V.D. Ovchinnik, V. N. Pirogov, N. N. Hal'ko, D. S. Shvarkov. Program-apparatus complex for investigation of gamma and $X$-rays radiations, generated by relativistic electrons in crystals: Preprint. Kharkiv: KIPT, 1991, 14 p.

2. J. Freudenberger, V. B. Gavrikov, M. Galemann, H. Genz, L. Groening, V.L. Morokhovskii, V.V.Morokhovskyi, U. Nething, A. Richter, J.P. F. Sellschop, and N.F. Shul'ga. Parametric X-ray Radiation Observed in Diamond at Low Electron Energies // Physical Review Letters. 1995, v.74, N13, p.24-87-2490.
3. D. I. Adejshvili , V. B. Gavrikov, V.L. Morokhovskii. About interference between parametric $X$-ray radiation of type $B$ and coherent bremsstrahlung of a fast charged particle in $f$ crystal: Preprint KIPT 69-00, Kharkiv, 1991, $10 \mathrm{p}$.

4. J. Freudenberger, H. Genz, L. Groening, P. Hofmann-Staschek, W. Knupfer, V.L. Morokhovskii, $\quad$ V.V. Morokhovskyi, U. Nething, A. Richter, J.P. F. Sellschop. Channeling radiation and parametric X-radiation at electron energies below $10 \mathrm{MeV} / / \operatorname{NIM}(B)$. 1996, v.119, p.123-130.

5. V.L. Morokhovskii,

D. I. Adejshvili, V.B. Gavrikov. Coherent X-radiation, generated by relativistic electrons in a crystal below the parametric X-radiation threshold // Ukrainian Physical Journal. 1993, v.38, N3, p.389-397.

6. V.L. Morokhovskii,

D. I. Adejshvili, V.B. Gavrikov, S. V.Kas'ean. Coherent XRay Radiation from Relativistic Electrons in a Crystal // Journal of Georgian Physical Society A. Particles and Nuclei. 1996, v.3, p.66-75.

7. B. G. Fedorkov, B. F. Teketz. Microschems of figure-amplitude-transformations and amplitudefigure-transformations: function, parameters, application. Moscow: "Energy-AtomPublishing", 1990, 320 p.

\section{КОНВЕРТОР ЗАРЯД-ЧИСЛО ИМПУЛЬСОВ}

\section{В. Л. Мороховский, В. В. Мороховский, В. Н. Пирогов}

Описан конвертор заряд-число импульсов, который успешно применялся в "Программно-аппаратурном комплексе для исследования $\gamma$ - и рентгеновского излучений, генерируемьх релятивистскими электронами в кристаллах"[1] на Харьковских линейных электронных ускорителях. Этот прибор предназначен для измерений заряда пучков высокоэнергетичных электронов (позитронов) с точностью до $2 \cdot 10^{-10} C$ и измерения токов в интервале величин $10^{-10} \ldots 10^{-8} \mathrm{~A}$.

\section{КОНВЕРТОР ЗАРЯД-ЧИСЛО ІМПУЛЬСІВ}

\section{В. Л. Мороховсъкий, В. В. Мороховсъкий, В. М. Пірогов}

Описано конвертор заряд-число імпульсів, який був успішно застосований в "Програмно-апаратурному комплексі для дослідження $\gamma$ - та рентгенівського випромінювань, які генерируються релятивістськими електронами в кристалах" [1] на Харківських лінійних прискорювачах електронів. Цей прилад призначений для вимірювання заряду пучків високоенергетичних електронів (позитронів) з точністю до $2 \cdot 10^{-10} C$ та вимірювання струмів в інтервалі величин $10^{-10} \ldots 10^{-8} \mathrm{~A}$. 